Diabetologia 7, 266-282 (1971)

(C) by Springer-Verlag 1971

\title{
The Ultrastructure of the Human Pancreatic Islets I. The Islets of Adults*
}

\author{
J.F. Deconinck, P.R. Potvlifege and W. Gepts
}

Department of Pathology, Brugmann University Hospital and Queen Elisabeth Foundation, Vrije Universiteit Brussel, Brussels, Belgium

Received: February 24, 1971, accepted: May 26, 1971

Summary. The ultrastructure of the pancreatic islets was studied in seven surgical specimens of human pancreas. The effects of two different fixation methods were compared : osmium tetroxide alone and glutaraldehyde followed by osmium. On the basis of their ultrastructural characteristics, four main types of islet cells were identified: 1. B cells, with polymorphous, often crystalline granules contained in wide sacs. 2 . A cells with rounded granules enclosed in tight fitting saes and composed of an electron-dense core surrounded by a clearer halo. 3. Type III cells, with rounded, large homogeneous granules of varying sizes and electron densities. They presumably secrete gastrin. Comparable cells were found in samples of human gastric and duodenal mucosae. 4. Type IV cells, with rounded, small, homogeneous granules of low electron density. Comparable cells were found in human gastric and duodenal mucosae. The nature of their secretion remains obscure. A fifth cell type was observed in the pancreas but was not restricted to the islets. Cells of type $V$ have small, polymorphous and very electron-dense granules. They offer a certain resemblance with the serotonin secreting cells which are found in the digestive tract.

L'ultrastructure des ilots de Langerhans de pancréas humains. I. Les îlots des adultes

Résumé. L'ultrastructure des îlots de Langerhans a été étudiée sur des prélèvements chirurgicaux de sept pancréas humains. Les effets de la fixation par le tétroxyde d'osmium seul et par la glutaraldéhyde suivie d'osmium ont été comparés. Quatre types cellulaires ont pu être identifiés: 1. Cellules B, à granulation polymorphe, de structure fréquemment cristalline, incluses dans de larges vésicules. 2. Cellules A à granules arrondis, composés d'un noyau dense entouré par un halo clair et inclus à l'étroit dans une enveloppe membranaire. 3. Cellules du type III à grosses granulations arrondies, de structure homogène, de densité et de forme variables. Ces cellules sécrètent peut-être de la gastrine. Des éléments similaires ont été rencontrés dans les muqueuses gastrique et duodénale. 4. Cellules du type IV, à petites granulations homogènes et pâles. Des éléments similaires ont été aperçus dans les muqueuses gastrique et duodénale; leur fonction reste inconnue. Des cellules d'un cinquième type se voient dans le pancréas, même en dehors des îlots. Elles sont caractérisées par de petits granules, très denses et polymorphes: elles offrent une certaine ressemblance avec les cellules à sérotonine que l'on trouve dans le tube digestif.

Die Ultrastruktur der Inseln des menschlichen Pankreas. I. Die Inseln von Erwachsenen

Zusammenfassung. Die Ultrastruktur der Langerhansschen Inseln wurde an Hand von chirurgischen Probeexzisionen an 7 menschlichen Pankreata studiert. Die Ergebnisse der Fixierung durch Osmium-Tetraoxyd einerseits und durch Glutaraldehyd gefolgt von Osmium anderseits wurden verglichen. So konnten vier Zelltypen identifiziert werden: 1. B-Zellen mit polymorphen, und oft kristallinen Granulationen, die in breiten Säckchen einge. schlossen sind. 2. A-Zellen, mit runden Granulationen und einem dichten Kern, welcher von einem hellen Hof umgeben ist und durch eine Membran eng eingehüllt wird. 3 . Ein dritter Zelltyp, mit dicken, runden, homogenen Granulationen veränderlicher Form und Dichte. Diese Zellen sezernieren vielleicht Gastrin. Gleichartige Zellen wurden in der Magen- und Duodenumschleimhaut gefunden. 4. Ein vierter Zelltyp, mit kleinen, bleichen und homogenen Granulationen. Gleichartige Zellen wurden in der Magenund Duodenumschleimhaut gefunden. Thre Funktion ist unbekannt. Man kann im Pankreas, auch außerhalb der Inseln, einen fünften Typ von Zellen sehen. Er unterscheidet sich durch kleine, sehr dichte, polymorphe Granulationen. Sie gleichen einigermaßen den Serotonin-Zellen des Darmes.

Key-words. Human pancreas - islets of Langerhans, ultrastructure, human gastric mucosa, human duodenal mucosa, endocrine cells.

\section{Introduction}

Studies on the ultrastructure of the pancreatic islet cells of man are relatively rare. Some among them have been performed on insulin-producing islet cell tumours (Bencosme et al. 1960, 1963; Porta et al. 1962; Greider et al. 1963, 1964; Honjin et al. 1965), and therefore give information on tumoural B cells only.

* This study has been presented in part at the 5 th annual meeting of the European Association for the study of Diabetes (September 1969, Montpellier, France).
Furthermore, many studies date from a time when the methods of fixation and embedding had not yet achieved a sufficiently satisfactory level. Whereas most authors agree on the existence and on the ultrastructural characteristics of two types of islet cells (A and $B$ cells), they differ in respect to the very existence and the characteristics of other types of islet cells.

Already at the level of light microscopy, a great confusion exists regarding the cell types composing the pancreatic islets. The A and $\mathrm{B}$ cells were deseribed by Lane in 1907, the $\mathrm{C}$ cell by Bensley in 1911, and the 
D cell by Bloom in 1931. Thomas (1937) reported $\mathrm{D}$ cells to be present in all the 41 mammalian species which he had examined, but stated that $\mathrm{C}$ cells are present only in the guinea pig. Various types of silver methods were also applied to the pancreas. For a long time it was admitted that silver-positive cells are identical to A cells, but more recently dissenting views have been expressed. Creutzfeldt and Theodossiou (1957), and Gepts (1957) stated that, at least with the silver methods they had used (respectively GrossSchulze and Holmes), not only were all A cells silverimpregnated but also a small number of B cells. On the other hand, Volk et al. (1955) declared that the Davenport silver method blackens only part of the A cells. This finding was confirmed later on by Hellman and Hellerström (1961) and, as a consequence, these authors divided the A cells in two groups, the argyrophylic A1 and the non-argyrophilic A2 cells. The Swedish authors adduced ample evidence that the A2 cells produce glucagon, but they were unable to suggest a function for the A1 cells. The question also arose as to the relationship between the A1 cell and the D cell of Bloom (1931). Björkman et al. (1966), and Van Assche (1970) are reluctant to admit that these cells are identical, but Solcia (1964), Fujita $(1964,1966$, 1968) and Epple (1966) are of an opposite opinion.

Up to now, studies with the electron microscope have done little to clear up this confusion. Several authors describe only two types of islet cells (Lacy 1961, 1964; Zagury et al. 1961; Zagury 1962; Lazarus and Volk 1962; Herman et al. 1964, Schultrich 1966). Other authors admit of three or even four types. Thiery and Bader (1966), using silver impregnation techniques make a distinction between argyrophylic and nonargyrophilic A cells. Björkman et al. (1966), studying human foetal islets, come to a similar conclusion and, in addition, describe a fourth type of cell, the agranular cell. However, Lacy $(\mathbf{1 9 6 1}, \mathbf{1 9 6 4})$ and Herman et al. (1964), consider these cells to represent either totally degranulated A and B cells, or the agranular poles of the cytoplasms of the latter.

The aim of the present work is to define the cytological structure of the human pancreatic islets, as deduced from an electron microscopic study of seven surgical specimens of pancreatic tissue. Since some of the discrepancies which have been reported, might result from differences in fixation procedures, a comparison was made between a combined glutaraldehyde-osmic acid fixation and a fixation with osmic acid alone. To aid in the identification of some of the islet cells an electron microscopic study was also undertaken of the endocrine cells of human gastric and duodenal mucosae.

\section{Material and Methods}

The material of this study consists of specimens of pancreatic tissue obtained in the course of surgical procedures for non-pancreatic pathological conditions.
Table 1 gives clinical information about these seven cases. Except for case 3, there was no reason to suspect any abnormality in the endocrine function of the pancreas. In case 3 , an islet cell tumour was suspected but its existence was never proved, and moreover hypoglycaemia disappeared after surgical exploration (Table 1).

Table 1

\begin{tabular}{llll}
\hline Case Nr. & $\begin{array}{l}\text { Age } \\
\text { (years) }\end{array}$ & Sex & Clinical Diagnosis \\
\hline $\mathbf{1}$ & 20 & M & Bright's disease \\
\hline 2 & 25 & M & Bright's disease \\
\hline 3 & 62 & M & Hypoglycaemia \\
\hline 4 & 72 & F & Ampullary carcinoma \\
\hline 5 & 64 & M & Ampullary carcinoma \\
\hline 6 & 76 & F & Ampullary carcinoma \\
\hline 7 & 62 & M & Gastric carcinoma \\
\hline
\end{tabular}

In each case, the fragment of pancreatic tissue was divided in two parts. One was fixed in Bouin's fluid, embedded in paraffin, sectioned at $5 \mu$ and stained with the chromium haematoxylin-phloxine method of Gomori (1941) and the aldehyde-thionin-trichrome method of Paget (1959). The other fragment reserved for electron microscopy, was primarily fixed for 2 hours in a $1.5 \%$ solution of purified glutaraldehyde (Anderson 1967) in $0.1 \mathrm{M}$ phosphate buffer at $\mathrm{pH} 7.4$, and post-fixed for $1.5 \mathrm{~h}$ in a $1 \%$ solution of osmium tetroxide in the same buffer. In two cases, another part of the specimen was primarily fixed for $1.5 \mathrm{~h}$ in a $1 \%$ solution of osmium tetroxide in $0.1 \mathrm{M}$ phosphate buffer at $\mathrm{pH}$ 7.4.

Specimens of gastric and duodenal mucosae were obtained from two patients operated upon for a gastric ulcer. These specimens were fixed for 2 hours in a $2.5 \%$ solution of purified glutaraldehyde in $0.075 \mathrm{M}$ cacodylate buffer at $\mathrm{pH} 7.4$ and post-fixed for $1.5 \mathrm{~h}$ in a $1 \%$ solution of osmium tetroxide in $0.1 \mathrm{M}$ cacodylate buffer, $\mathrm{pH} 7.4$.

Fixation and dehydration were carried out at $4^{\circ} \mathrm{C}$. The specimens were embedded in Durcupan (pancreas) or in Epon (gastric and duodenal mucosae). Pancreatic islets and endocrine cells of the gastric and duodenal mucosae were located in semi-thin sections stained by an alcoholic solution of safranin. Ultrathin sections were contrasted with permanganate (Reedy 1965) and Reynold's solution (1963) for the pancreatic material, and with uranyl acetate and Karnowsky's stain (1961) for the gastro-duodenal mucosa. The sections were then examined with a Zeiss EM9A electron microscope.

\section{Results}

Light microscopy. In all seven cases, the histological appearance of the islets was completely normal. The $A$ and $B$ cells were well granulated. With the trichrome 


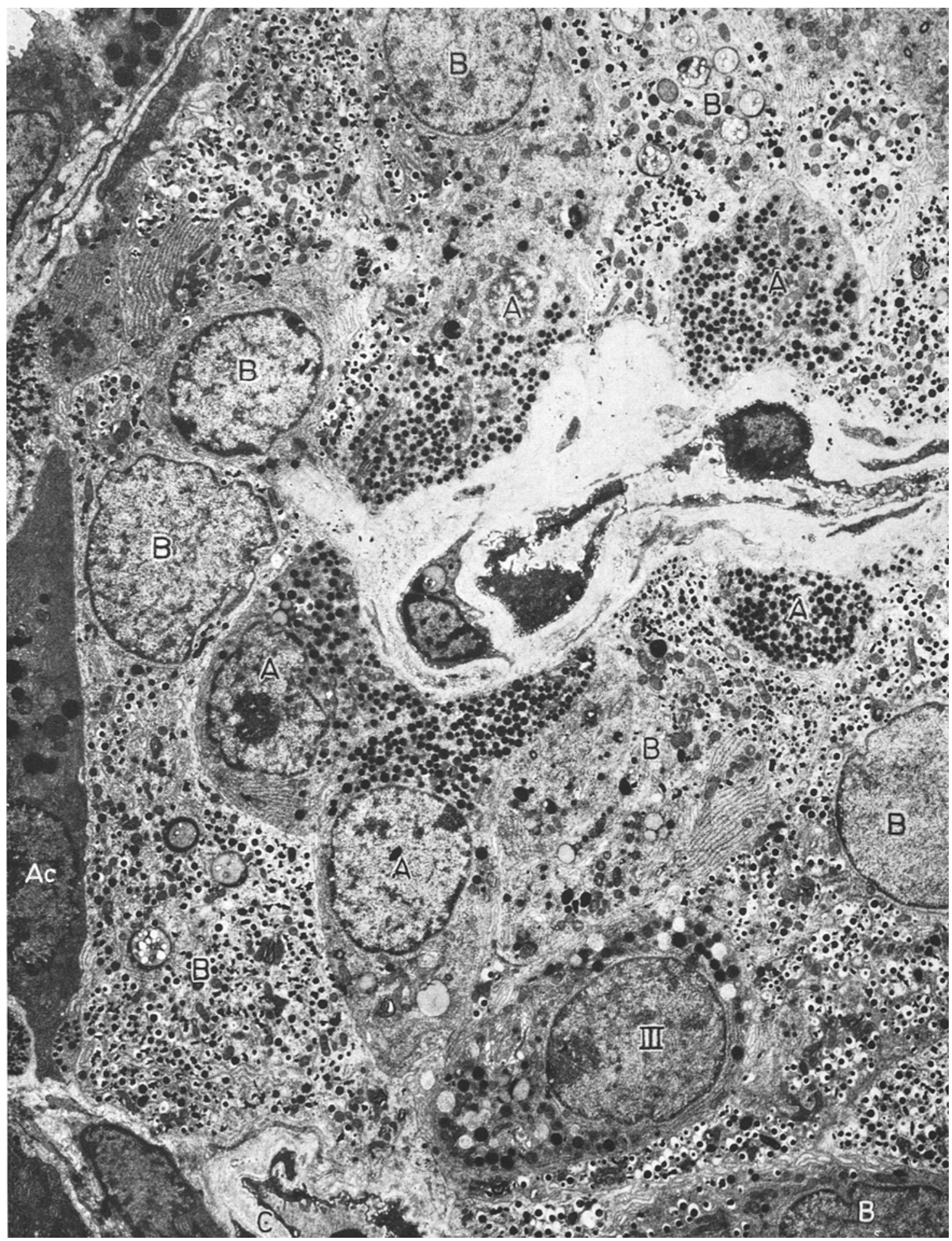

Fig. 1. General view of the periphery of an islet, separated from surrounding acinar tissue, one cell of which however (Ac) lies within the islet. A central capillary is surrounded mostly by A cells (A), the granules of which accumulate at the capillary poles. Numerous B cells (B) are scattered randomly. A type III cell (III) is seen in close proximity of an interstitial capillary (c). (Glutaraldehyde - Osmium $\times 5100$ ) 


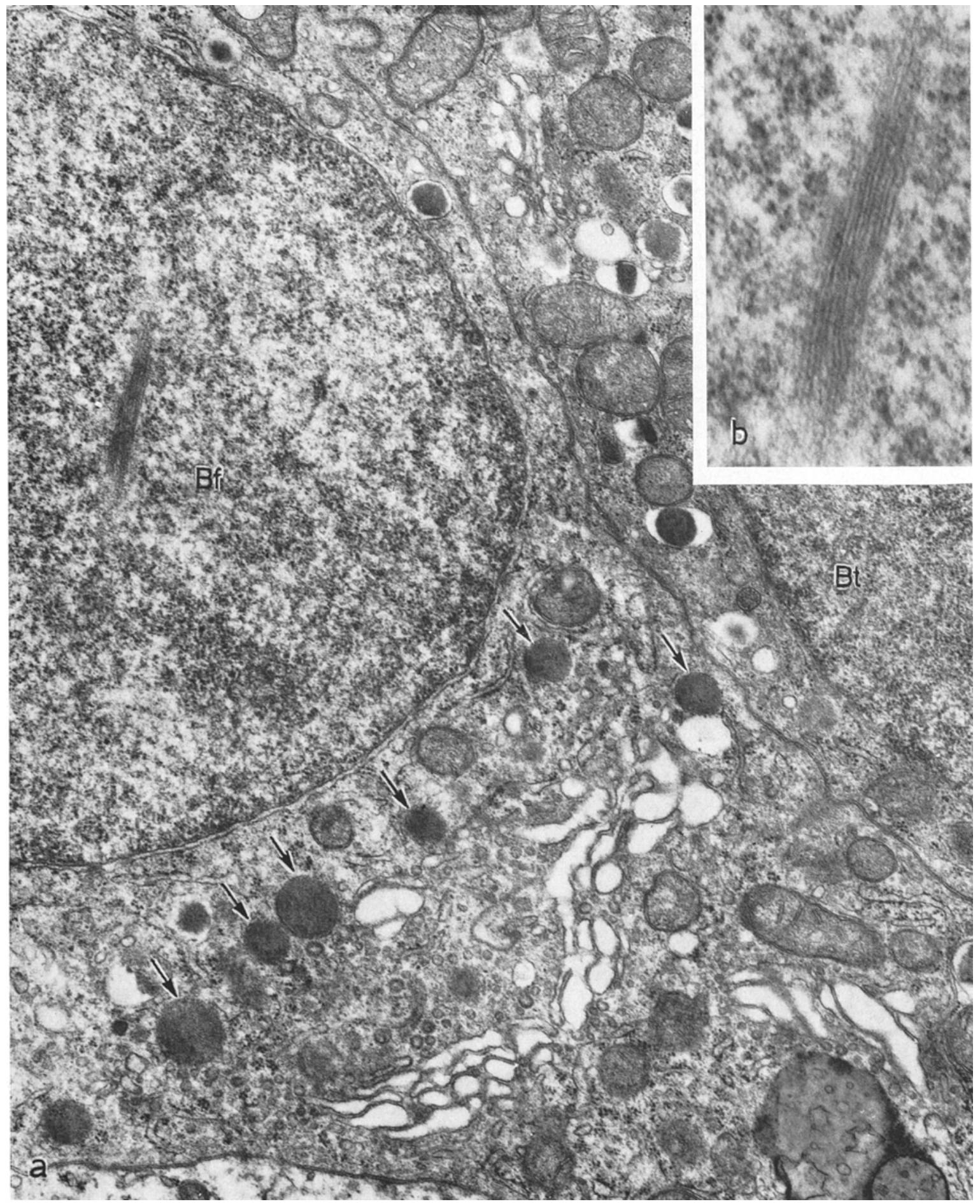

Fig. 2 a. Parts of two B cells (Bf and Bt). The nucleus of Bf contains a fibrillar inclusion. Bt shows typical granules whereas $\mathrm{Bf}$ contains some atypical granules of more homogeneous appearance and of lower electron density (7). Bf also exhibits a well developed Golgi apparatus (Glutaraldehyde - Osmium $\times 21000$ ). b. In insert, higher magnification of the nuclear fibrillary inclusion. (Glutaraldehyde - Osmium $\times 54000$ ) 
method a small number of $\mathrm{D}$ cells were identified. No granular cells were found.

Electron microscopy. The islets of endocrine tissue were easily distinguished from the exocrine tissue by a more diffuse and finer granularity of their cells (Fig. 1). However the limits between isiet and acinar tissues were not always clearcut. In some places the islet cells were separated from typical acinar cells by agranular cells which sometimes lined a small lumen. These cells are probably centro-acinar cells. Typical A and B cells were also present among the epithelial cells of larger excretory ducts. No difference was observed between
1. The $B$ cells. The $B$ cells had a round or oval, occasionally slightly indented nucleus. After glutaraldehyde osmic acid fixation the chromatin was more clumped and aggregated along the nuclear membrane than after osmic acid fixation alone. Small fibrillar inclusions were found in the nucleus of a few B cells (Fig. 2). They were never seen after osmic acid fixation alone. Neither were they found in any other type of islet cells, irrespective of the fixation used. Small clusters of B cells appeared to have two or three nuclei.

After glutaraldehyde osmic acid fixation the general appearance of the cytoplasm of the B cells

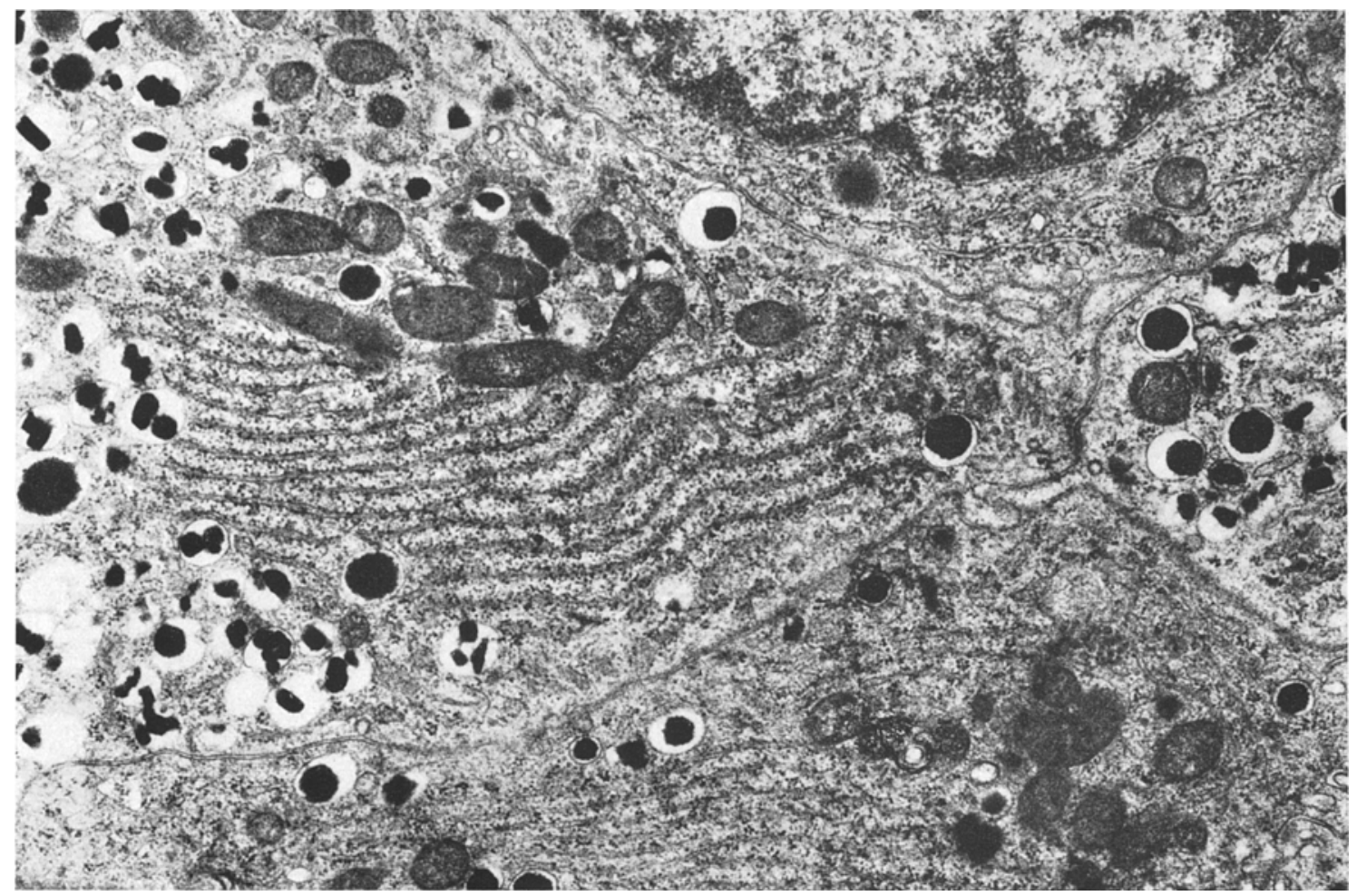

Fig. 3. Parts of four B cells with a well developed endoplasmic reticulum forming parallel arrays of flattened sacs limited by rough membranes. (Glutaraldehyde - Osmium $\times 21000$ )

the ductal endocrine cells and those composing the islets. The islet cells were always separated from the lumen of the capillaries by a double basement membrane, one under the endothelium and the other close to the islet cells (Fig. 1). In the intermembranous space there were a small number of collagen fibres and fibroblasts (Fig. 1).

In the islets four main types of cells were identified on the basis of their ultrastructural characteristics. In order of frequency these cells are B, A cells and cells of types IV and III. Another type of endocrine cell, possibly serotonin secreting, could also be found in the pancreas, where its location was not restricted to the islets. appeared more crowded than after osmic acid alone. This is probably due to a better preservation of the cytoplasmic organelles with the double fixation method. Interdigitations between $\mathrm{B}$ cells, and between these cells and other types of endocrine cells were a common feature. Desmosomes were relatively rare, but were observed between all types of islet cells. The mitochondria of the B cells were round, rod-like or filamentous with transversal cristae. Myelinic figures, were often found in close spatial relationship with mitochondria (Fig. 7). Other lipid inclusions of varying sizes and shapes, sometimes multivacuolated, were extremely common in the B cells of adults (Fig. 2, 4). Dense bodies were much rarer (Fig. 3, 4); they were 
generally small and of irregular shape. Profiles of rough endoplasmic reticulum could be found thoughout the entire cytoplasm, but were more evident in the sparsely granulated parts of the cell (Fig. 3). A small amount of free ribosomes was scattered between the cytoplasmic organelles. One or two centrioles could often be found, sometimes near the Golgi area. The Golgi apparatus was of moderate to prominent size empty-looking space which was limited by a smooth single membrane.

A small number of $B$ cells contained granules of atypical appearance that had a less electron-dense core, a faintly granular structure, and were more closely fitted in a smooth sac (Fig. 2, 4). Such granules were rarely found intact after osmic acid fixation alone; they closely resembled the granules of the fourth cell

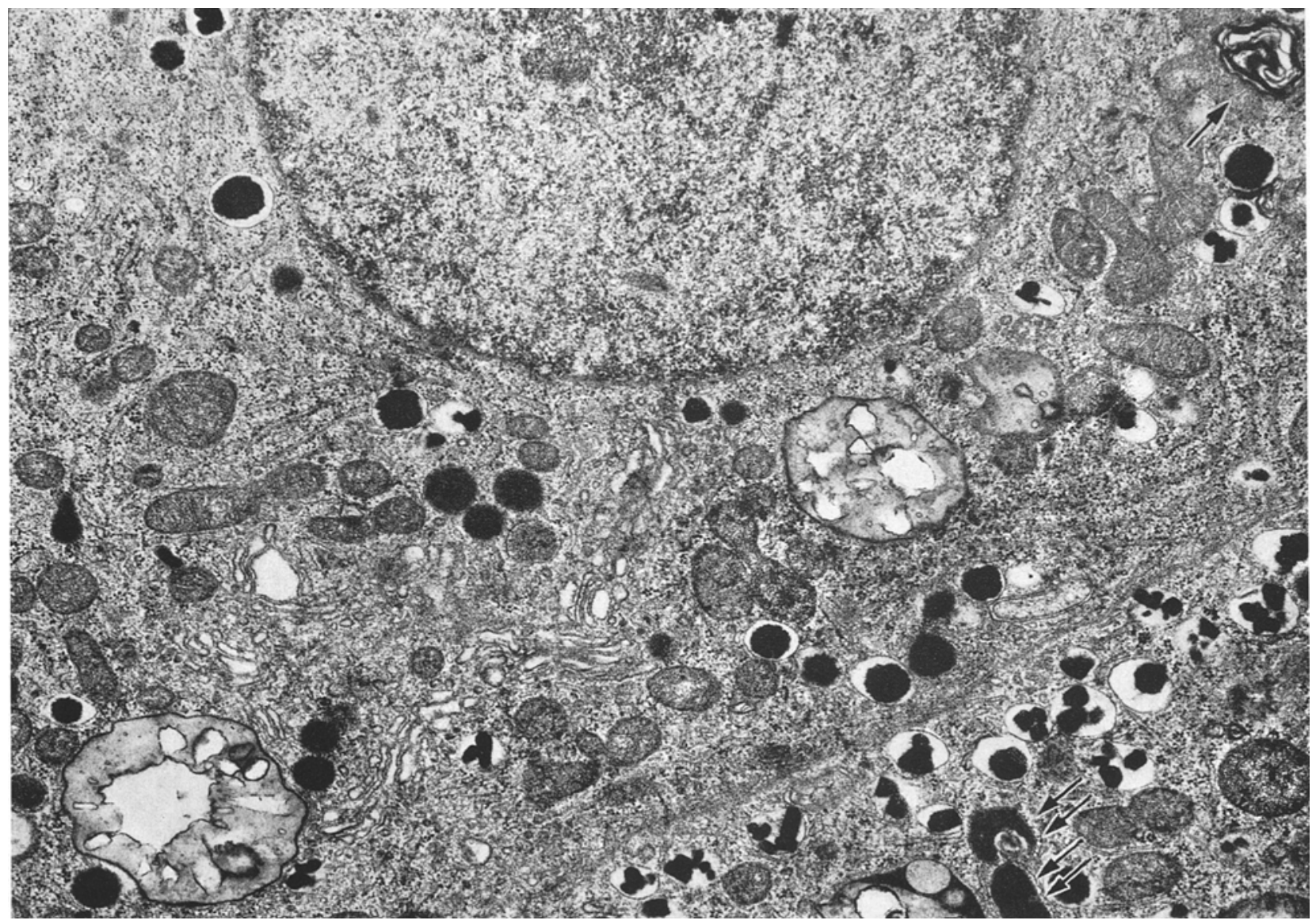

Fig. 4. Parts of two B cells (B). One B cell displays a well developed Golgi complex with, in its vicinity, some atypical granules. One of the mitochondria $(A)$ encloses a myelinic figure. The other B cell shows two irregularly shaped dense bodies $(\nearrow, /)$. (Glutaraldehyde-Osmium $\times 21000)$

(Fig. 2, 4). Some of the Golgi vesicles contained a small amount of amorphous, moderately electron-dense material which had the appearance of minute $\mathrm{B}$ secretory granules.

The secretory granules represented the most characteristic feature of the $\mathrm{B}$ cell. They often accumulated towards the capillary pole (Fig. 1). They had an overall diameter of 350 to $500 \mathrm{~m} \mu$, and were composed of an electron-dense core contained within a wide sac. The core was quite polymorphous, and could take the shape of a sphere, a bar, a needle or a fragmented crystalloid. Around the core there was a wide, type which is described below; they are to be distinguished from the latter by the fact that they occured, in small numbers, in otherwise typical B cells, beside granules of the usual type.

In the gastric and duodenal mucosae, we were unable to identify $\mathrm{B}$ cells.

2. The $A$ cells. The A cells were generally located at the periphery of the islets or near the capillaries. Their nucleus did not differ markedly from that of $B$ cells. Their cytoplasm had a darker appearance than that of the B cell, probably because of the presence of a larger number of free ribosomes. The mitochondria were 
round, rod-like or filamentous with transversal cristae; they appeared smaller and less numerous than those of the $\mathrm{B}$ cells and the filamentous forms, more elongated. than in the B cells, predominated. Myelinic figures, often in close relationship with mitochondria, were more nimerous and larger than in B cells (Fig. 7). Other lipid inclusions were less numerous and smaller than in B cells (Fig. 5, 6). The Golgi complex was being sometimes electron-lucent. The size of the granules ranged from 350 to $450 \mathrm{~m} \mu$ in diameter.

In the duodenal and gastric mucosae we were unable to identify A cells.

3. Cell type III. Cells of this type were rare. They could be found at the periphery of islets or near capillaries. They had an elongated shape; they were generally surrounded by $B$ cells with which they

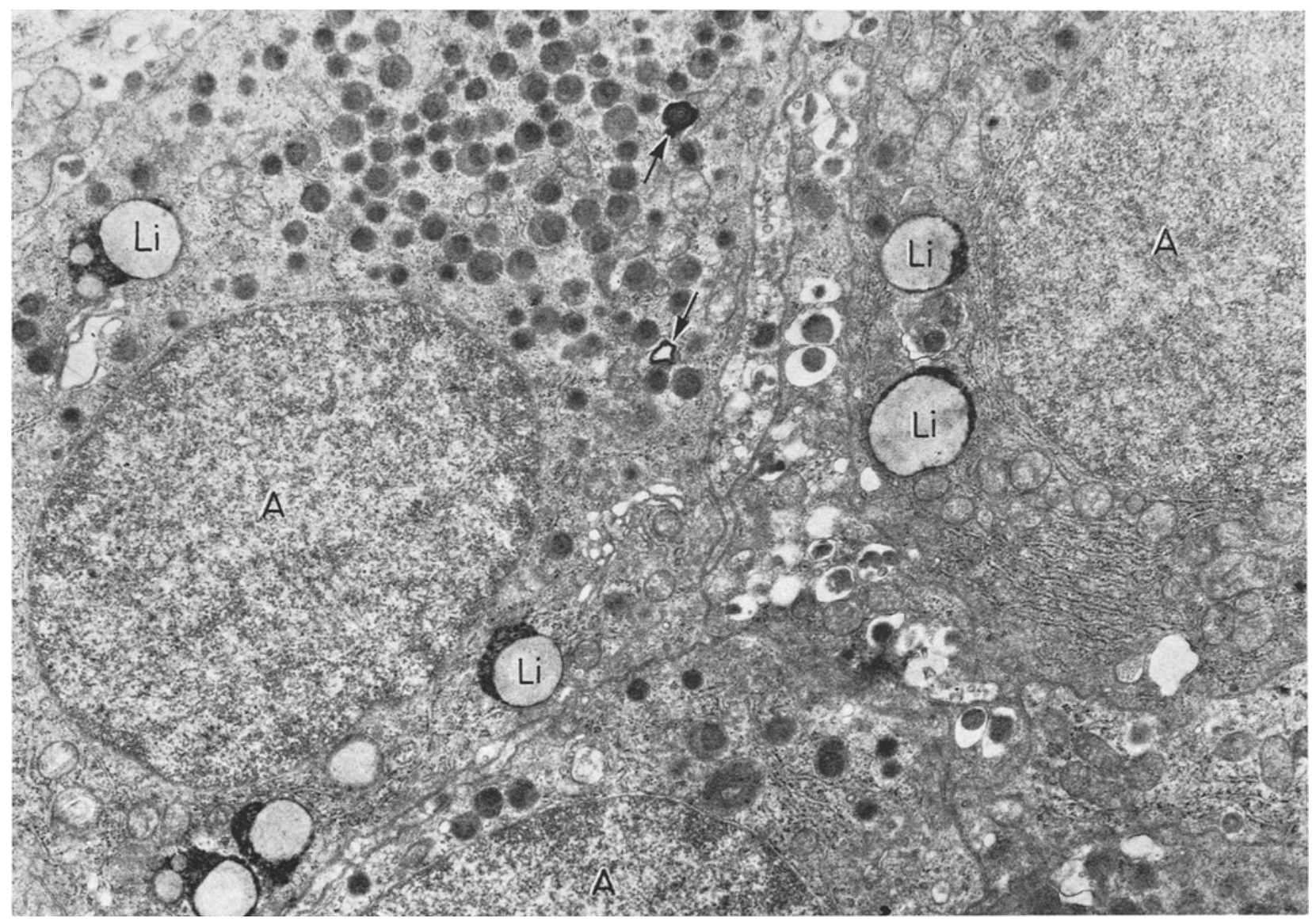

Fig. 5. Parts of three A cells (A) with, in between, a very small part of a B cell. One A cell displays numerous typical secretory granules, a small Golgi apparatus, several lipid inclusions (Li) and two myelinic figures $(\nearrow)$. (Glutaraldehyde - Osmium $\times$ 12000)

usually small (Fig. 5). Dense bodies were often present, whereas centrioles were rare.

The secretory granules of the A cells had a characteristic appearance. As in B cells they were often concentrated towards the capillary pole of the cell. After glutaraldehyde fixation the granules exhibited a slightly eccentric, round, very electron-dense core, surrounded by a semi-lunar less dense area, and were enclosed in a tightly-fitting smooth membrane (Fig. 5). After osmic acid fixation alone, the dense core appeared more central and larger (Fig. 6), the surrounding halo was narrower and less electron-dense to the point of interdigitated slightly and to which they sometimes were united by desmosomes (Fig. 9). The nucleus was similar to that of the other cell types. The mitochondria resembled those of the $B$ cells. Myelinic figures and lipid inclusions were present, but were much smaller and less frequent than in the latter. A rough endoplasmatic reticulum, composed of flattened sacs, was particulary evident around the nucleus and in a sparsely granulated cellpole, but could be found throughout the entire cytoplasm. Free ribosomes were numerous. The Golgi complex, generally prominent, was located in the granular cellpole near the nucleus 


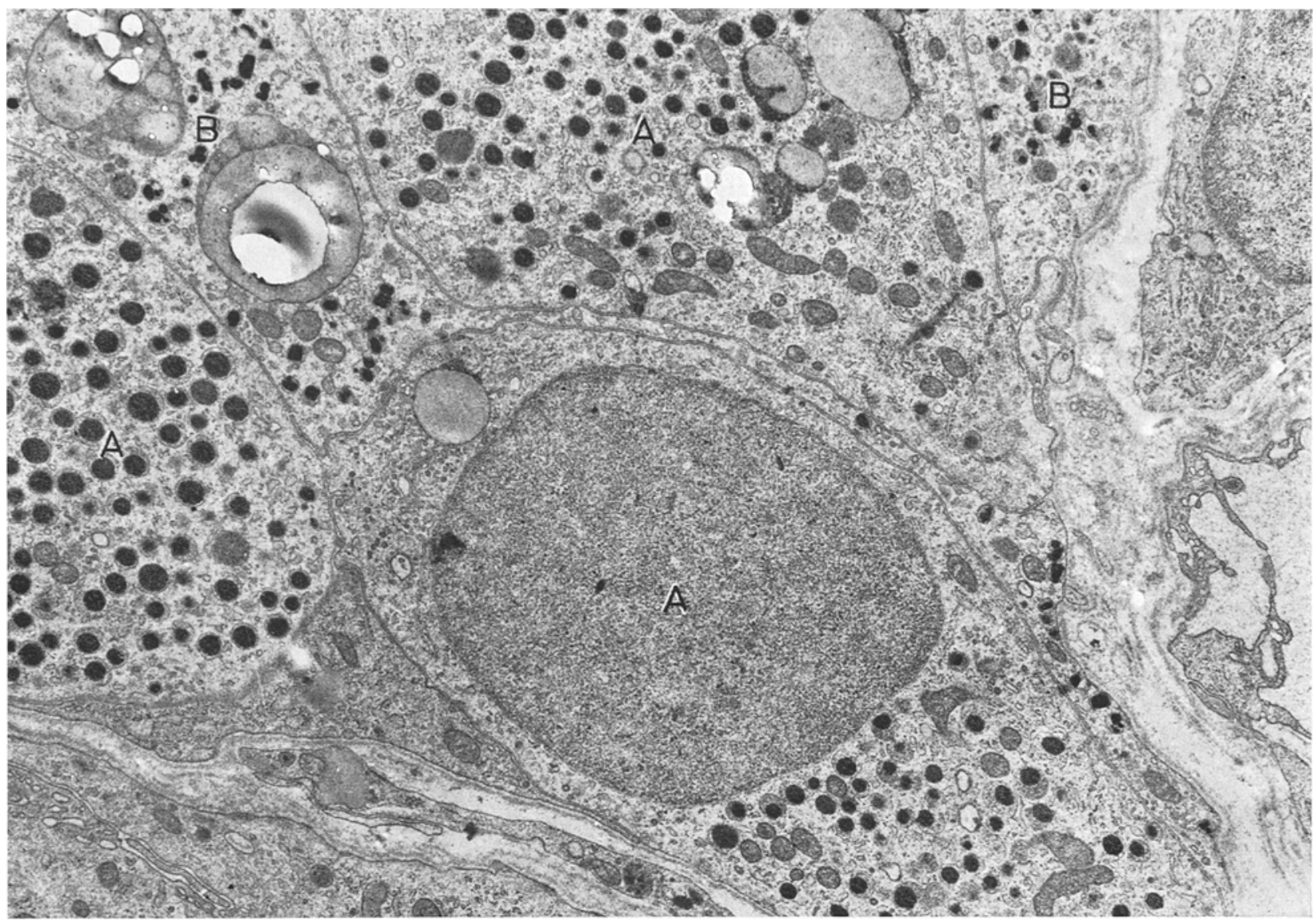

Fig. 6. Periphery of an islet showing parts of three A cells (A) and two B cells (B). By comparison with Fig. 5, the secretory granules here show a larger dense core, more centrally placed, surrounded by a narrower and less electron-dense halo; their limiting smooth membranes also are frequently interrupted (Osmium $\times 12000$ )

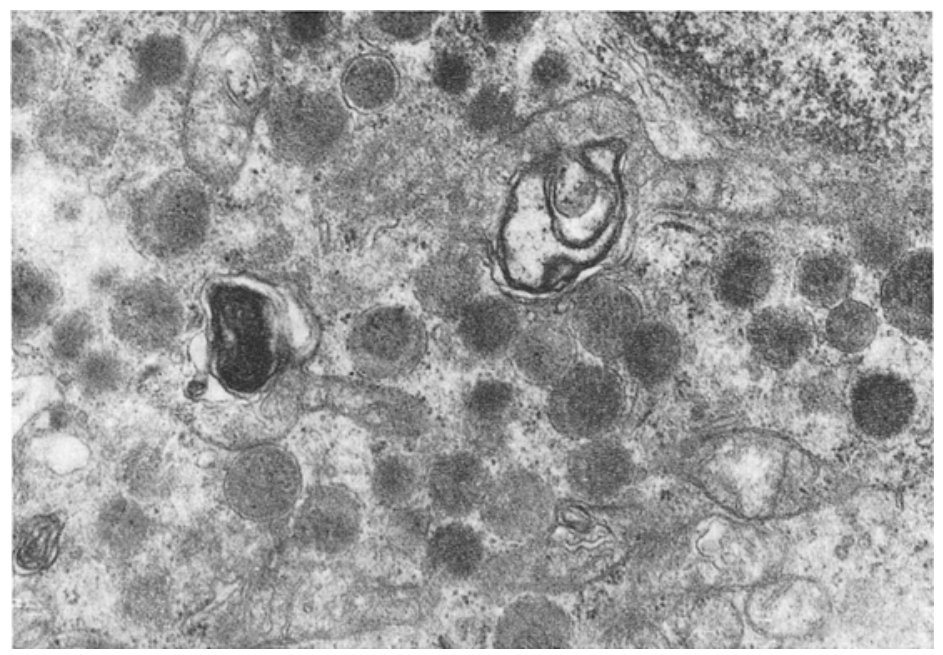

Fig. 7. This A cell contains three myelinic figures, one of which is enclosed within a mitochondrion (Glutaraldehyde - Osmium $\times 24500$ ) 
(Fig. 9). It consisted of flattened sacs, sometimes separated by narrow cytoplasmic bands of high electron density (Fig. 8), and might contain minute, dense granules of irregular shape (Fig. 8). The secretory granules displayed a marked vascular polarity; they were large, having an overall diameter of 450 to $800 \mathrm{~m} \mu$. Their core exhibited a considerable variation in electron density and was closely fitted in a smooth sac. The largest granules typically were of low electron density, had a faintly granular structure and were located near the cell membrane. The smaller granules of their nucleus and cytoplasm resembled that of the A cells. They could be identified by their secretory granules which, after glutaraldehyde fixation, exhibited a homogeneous, moderately electron-dense core, surrounded by a closely fitting smooth membrane. The size of these granules ranged between 350 and $500 \mathrm{~m} \mu$. They displayed a marked vascular polarity. The Golgi complex was generally small and often contained. minute granules. The cytoplasm frequently contained lipid inclusions. Similar cells were found in the gastric and duodenal mucosae.

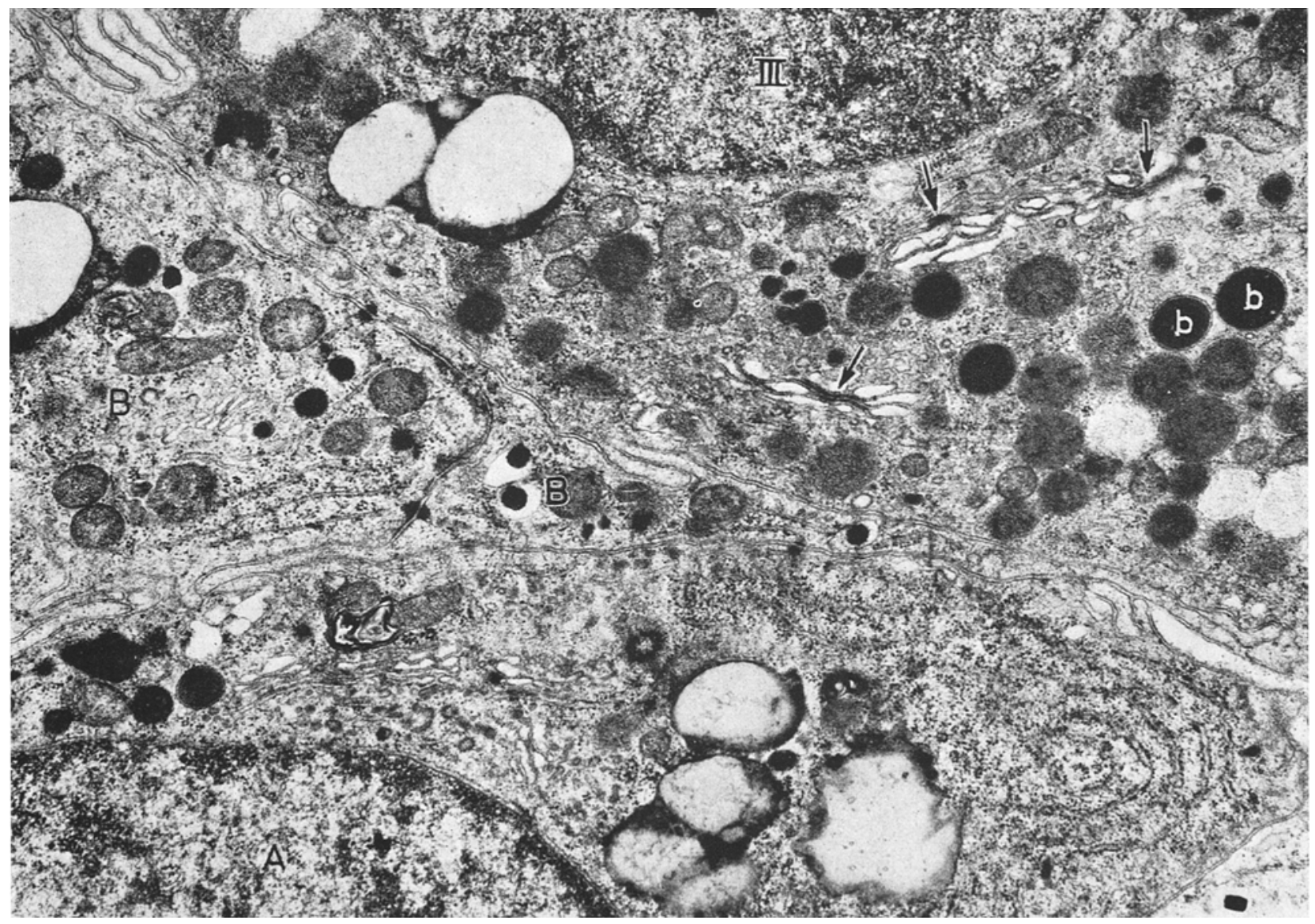

Fig. 8. Parts of two B cells (B), a type III cell (III) and a A cell (A). The type III cell is characterized by: a) large granules of variable electron densities; b) dark bands of cytoplasm separating Golgi cisternae $(\vec{f})$; c) large rounded bodies of high electron densities (b). Minute irregularly shaped secretory granules are seen in the Golgi area. (Glutaraldehyde - Osmium $\times 21000$ )

were more often located in the vicinity of the Golgi complex, and usually were electron dense. However, some large spherical granules of a high and homogeneous electron density might be found. Similar cells were found in the gastric and duodenal mucosae (Fig. 10).

4. Cell type $I V$. Cells of this type were also rare and, in contradistinction to those of type III, were often located in the vicinity of $A$ cells. The general structure
5. Cell type $V$. Cells of this type were extremely rare and in the pancreas were not restricted to the islets. Within the islets they were usually found among the A cells (Fig. 14). The general structure of their nucleus and cytoplasm resembled that of the $A$ cell. The secretory granules, however, were quite different. They were small, 150 to $300 \mathrm{~m} \mu$ of overall diameter, and consisted of a round, oval or coma-shaped electron- 
dense core, closely fitted in a smooth sac. As in all other endocrine cells, the granules accumulated towards the vascular pole. Similar cells were found in the gastric and duodenal mucosae (Fig. 15).

\section{Discussion}

$B$ and $A$ cells. Our description of the $\mathrm{B}$ and $\mathrm{A}$ cells is in general accord with that of other authors (Lacy 1961, Bencosme et al. 1963, Greider et al. 1963, Greider that the appearance of crystalline subunits in B cell granules of man occurs only at some distance from the Golgi complex. We have been unable to confirm this finding in our material.

The presence of B cells with two or three nuclei is surprising, since with the light microscope, such cells or cells having a markedly lobular nucleus are never seen. Intranuclear fibrillar inclusions have been described by Boquist (1969) in the B cells of obese, hyperglycaemic mice, but have not been reported before in the islets of man. Since these fibrillar in-

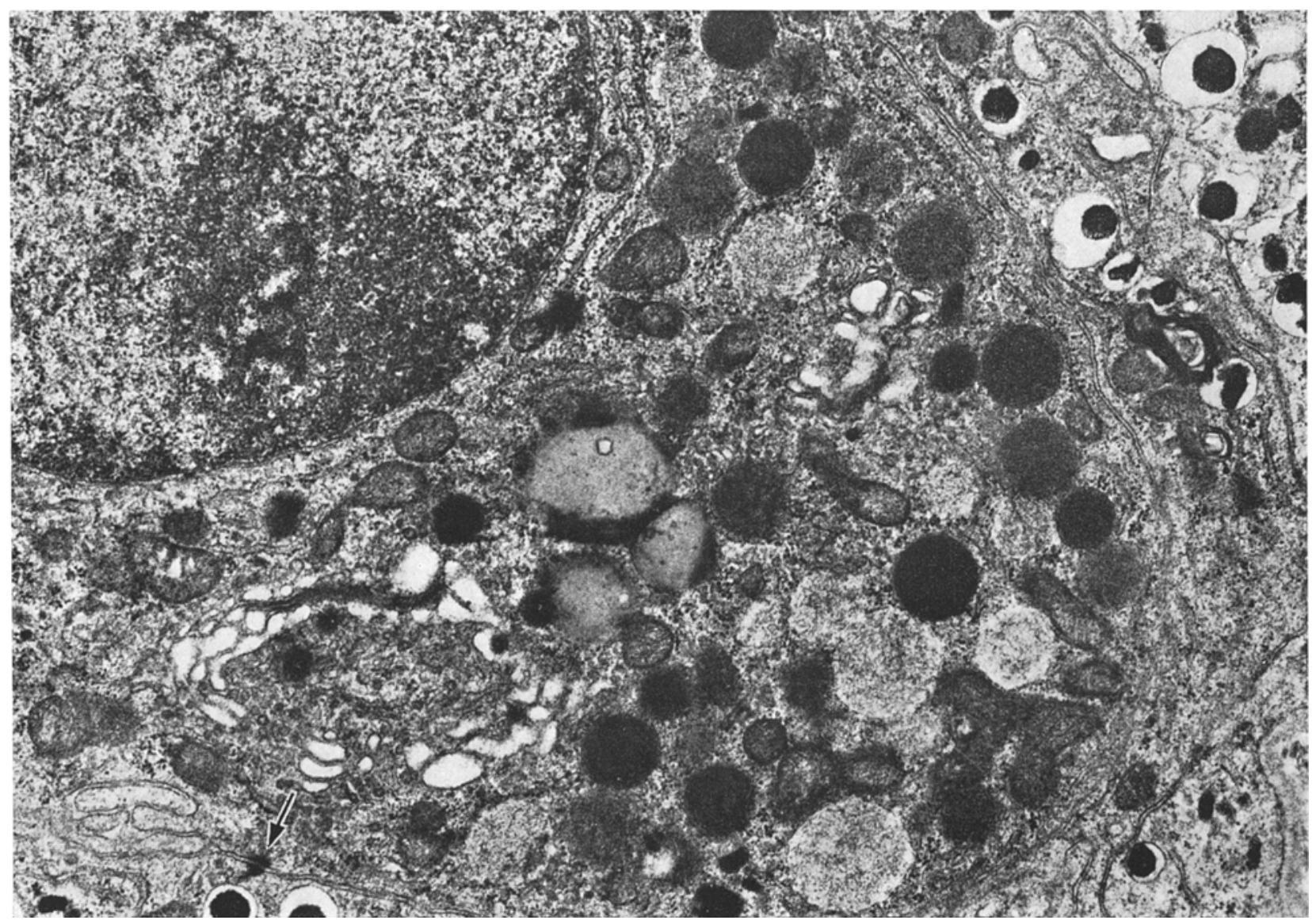

Fig. 9. Another example of a type III cell with the same general characteristics. A desmosome $(\nearrow)$ links the type III cell to a neighbouring B cell. (Glutaraldehyde - Osmium $\times 24500$ )

and Elliott 1964, Björkman et al. 1966, Hellman 1966, Schultrich 1966, and Like 1967). B cells with atypical granules were also described by Lacy 1961, Greider et al. 1963, and Like 1967. The significance of the different forms of B granules is still obscure. Lacy (1957) has suggested that they might be related to differences in the molecular structure of either insulin or insulin precursor. Kawanishi (1966) feels that the crystalloid granules represent mature forms. A similar opinion was expressed by Like (1967), who pointed out clusions have been found in B cells only, they seem to be related to the specific function of these cells, but their significance remains obscure.

The secretory mechanism of the pancreatic islet cells is still a matter of controversy. Lacy (1961), Lazarus and Volk (1962) Björkman et al. (1963), and Volk and Lazarus (1964) have described a process of emiocytosis, in which the granules migrate towards the cell membrane and are expelled in the extracellular space. Other authors (Munger 1962, Björkman 
and Hellman 1964, Munger et al. 1965, Lever and Findley 1966, and Legg 1967) have defended the view that insulin secretion can occur through an intracellular dissolution of granules or by direct secretion without passing through a granular form. Not the slightest evidence in favour of any of these mechanisms has been observed in our material. It is true that the membrane enclosing the granules sometimes shows interruptions. Similar findings have been reported by Lever and Findley (1966). However, we feel that such membrane defects are related to fixation artefacts, endocrine cells were found in the gastric and duodenal mucosae, which is in accordance with the observations of Orci et al. (1968), Forssmann et al. (1969), Lechago and Bencosme (1970), and Pearse et al. (1970).

In accordance with Like (1967) we found that the ultrastructure of the A secretory granules is influenced by the method of fixation. The semilunar halo which encircles the electron-dense core of the granules is less electron transparent after glutaraldehyde fixation than after primary osmic acid fixation. Lechago et al. (1968), and Shibasaki and Ito (1969) describe two

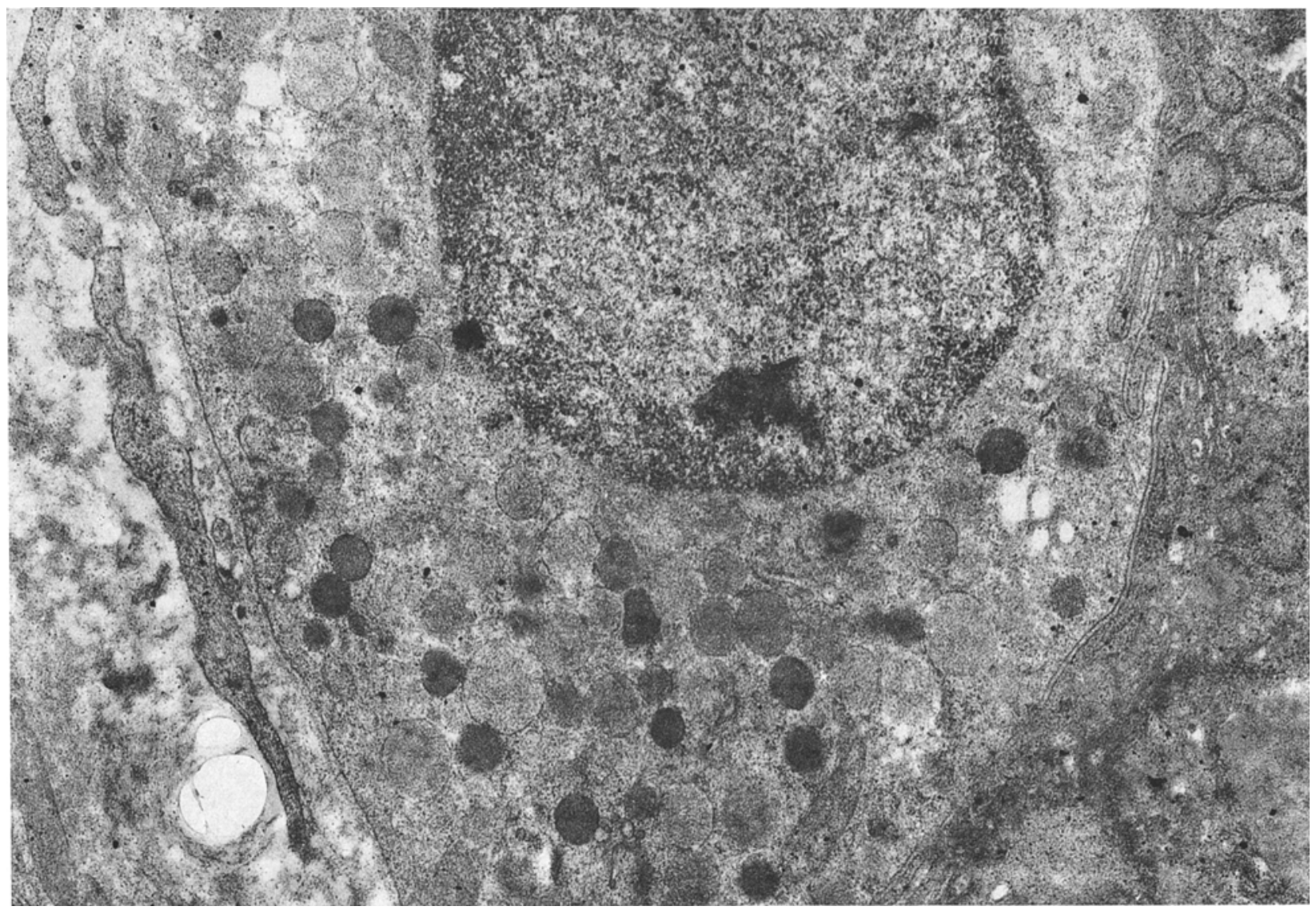

Fig. 10. A granular cell observed in the duodenal mucosa and exhibiting the same characteristics as an islet type III cell. (Glutaraldehyde - Osmium $\times 21000$ )

rather than to a hypothetical intracellular dissolution of granules.

The role of the Golgi apparatus in the secretory process is confirmed by the finding of minute secretory granules within the Golgi area, a phenomenon which was evident in all types of pancreatic endocrine cells. The appearance of the $B$ cell granules was not much affected by differences in fixation methods. With osmic acid fixation alone, however, the cytoplasmic organelles were less well preserved. No B-cell-like subtypes of A cells, characterized respectively by small and large granules. Greider et al. (1970) also observed A granules of variable sizes but side by side within the same cell. At least in adult material, we could find no convincing evidence of the existence of two different subtypes of A cells identifiable by the sizes of their granules. We were impressed by the abundance in A cells of adults of myelinic figures, often in close relationship to mitochondria, suggesting that they might result from mitochondrial degeneration. 
These myelinic figures are quite different from the lipid inclusions which have no relationship with mitochondria and are more numerous in $\mathrm{B}$ cells. We found no A cell like endocrine cells in our limited. material of gastric and duodenal mucosae.

Cell type III. Cells of type III are rare; after glutaraldehyde fixation they can be easily identified by the large size and the variable electron density of their secretory granules. Similar cells have been described by Like (1967), who considers them to be cells of the gastric and duodenal mucosae, as described by Orci et al. (1968), Forssman et al. (1969), Lechago and Bencosme (1970), and Pearse et al. (1970), and as were found in our own material. According to Orci, gastrin cells exihibit four characteristic ultrastructural features: 1) a variable diameter of the secretory granules which ranges from small to very large; 2) a variable electron-density of the secretory granules which varies from high density in small ones, to nearly lucid in large ones; 3 ) the presence of dense

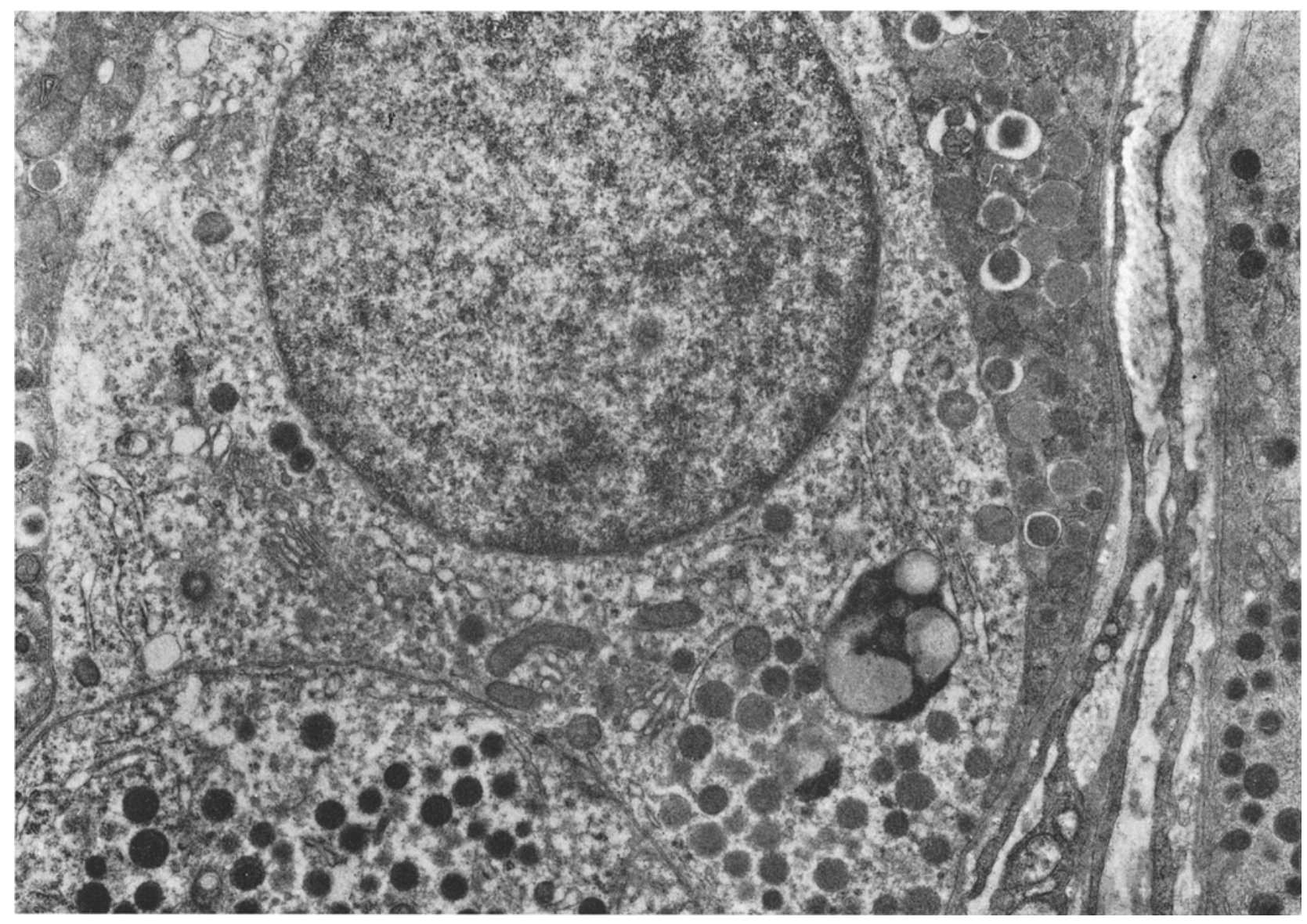

Fig. 11. Type IV cell defined by: a) homogenous rounded granules of the same size as A granules; b) a small Golgi apparatus; c) mitochondria resembling the A mitochondria (Glutaraldehyde - Osmium $\times 12000$ )

altered but viable A cells. In our experience, these cells must be difficult to fix since they lose their characteristic aspect after primary osmic acid fixation. When fixed by glutaraldehyde followed by osmic acid, however, these cells do not show the slightest indication of being altered: their cytoplasmic organelles are intact and the presence of secretory granules in their Golgi area demonstrates an active secretory function; nor do they in any way resemble A cells. On the other hand, they strikingly resemble the gastrin-secreting bodies surrounded by a narrow electron-lucent halo encased in a smooth membrane; 4) the existence of dark bands in the Golgi apparatus. All these characteristics were observed in our type III cells.

Further support for the existence of gastrinproducing cells in pancreatic islets comes from the works of Lomský et al. (1969) and Greider and $\mathrm{Mc}$ Guigan (in press) who, using immunofluorescent techniques, demonstrated the presence of gastrin in some cells of normal human islets. Other evidence, 
pointing in the same direction, comes from the existence of gastrin-producing pancreatic islet tumours, which are responsable for the Zollinger-Ellison syndrome. We have had no opportunity to study such a tumour, but pictures shown in the work of Creutzfeldt et al. $(1969 \mathrm{a}, \mathrm{b})$ demonstrate a marked similarity between his gastrin cells and our type III cells.

Cell type IV. Cells of this type may be differentiated from those of type III by the following ultrastructural features: 1) their mitochondria resemble those of
Bader (1966) and Potet et al. (1966). As regards their secretory function nothing definite is known. Hellman and Lernmark (1969) have adduced evidence in favour of the production, by pancreatic islet tissue, of a substance inhibiting insulin release from $\mathrm{B}$ cells and considers this substance to be secreted by A1 cells. However, with Björkman (1966), he is reluctant to admit that $A 1$ and $D$ cells are identical. The topographical situation of our type IV cells, amidst A cells, rather pleads against their exercizing such a

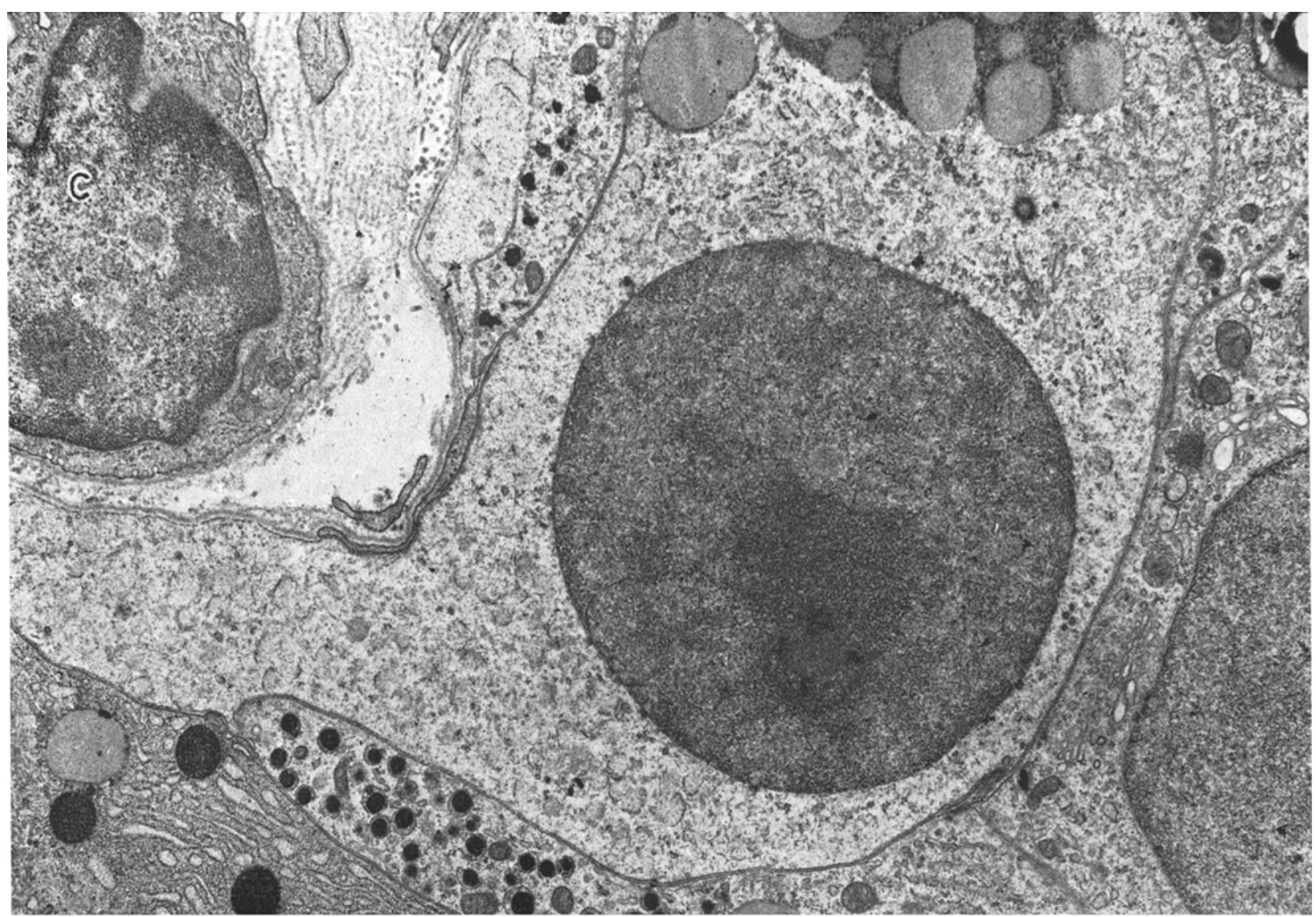

Fig. 12. Next to a capillary (c), an apparently agranular cell. Numerous shadows of the membranes of granules are seen (Osmium $\times 21000)$

A cells, whereas the mitochondria of type III cells resemble those of B cells; 2) a small Golgi apparatus, in comparison with a large one in type III cells; 3 ) small secretory granules $(350-500 \mathrm{m \mu})$, as against large ones $(450-800 \mathrm{~m} \mu)$, in type III cells; 4$)$ location amidst $A$ cells, in contradistinction with location in the vicinity of B cells for type III cells.

It appears to us that cells of our type IV are identical to the D cells of Shibasaki and Ito (1969) and the Al cells of Björkman et al. (1966), Thiery and function. As did Orci et al. (1968) in rats, and Pearse et al. (1970) in man, we found similar cells in the gastric and duodenal mucosae.

Cell type $\nabla$. To the best of our knowledge, cells of this type have never before been described in human pancreatic islets. By their general morphology they resemble the serotonin producing cells described by Orci et al. (1968) in the gastro-intestinal tract of rats and by Pearse et al. (1970) in the gastro-intestinal tract of man. However, the serotonin cells which we were 
able to identify in the gastric and duodenal mucosae of man, by virtue of the positive reaction of their granules with bichromate (Wood 1965), are different from the pancreatic cells of our type $V$ : their granules are definitely larger and more polymorphous. Unfortunately, we have had no opportunity to perform the this explanation since, in our micrographs, in every cell, at least a few typical granules were always present.

Acknowledgements. This work was supported by grant $n^{\circ} 1190$ of the Fonds National de la Recherche Scientifique Médicale. Sincere thanks are due to Mrs. H. De Backer for technical assistance, to Mr. C. Cortier for his valuable help

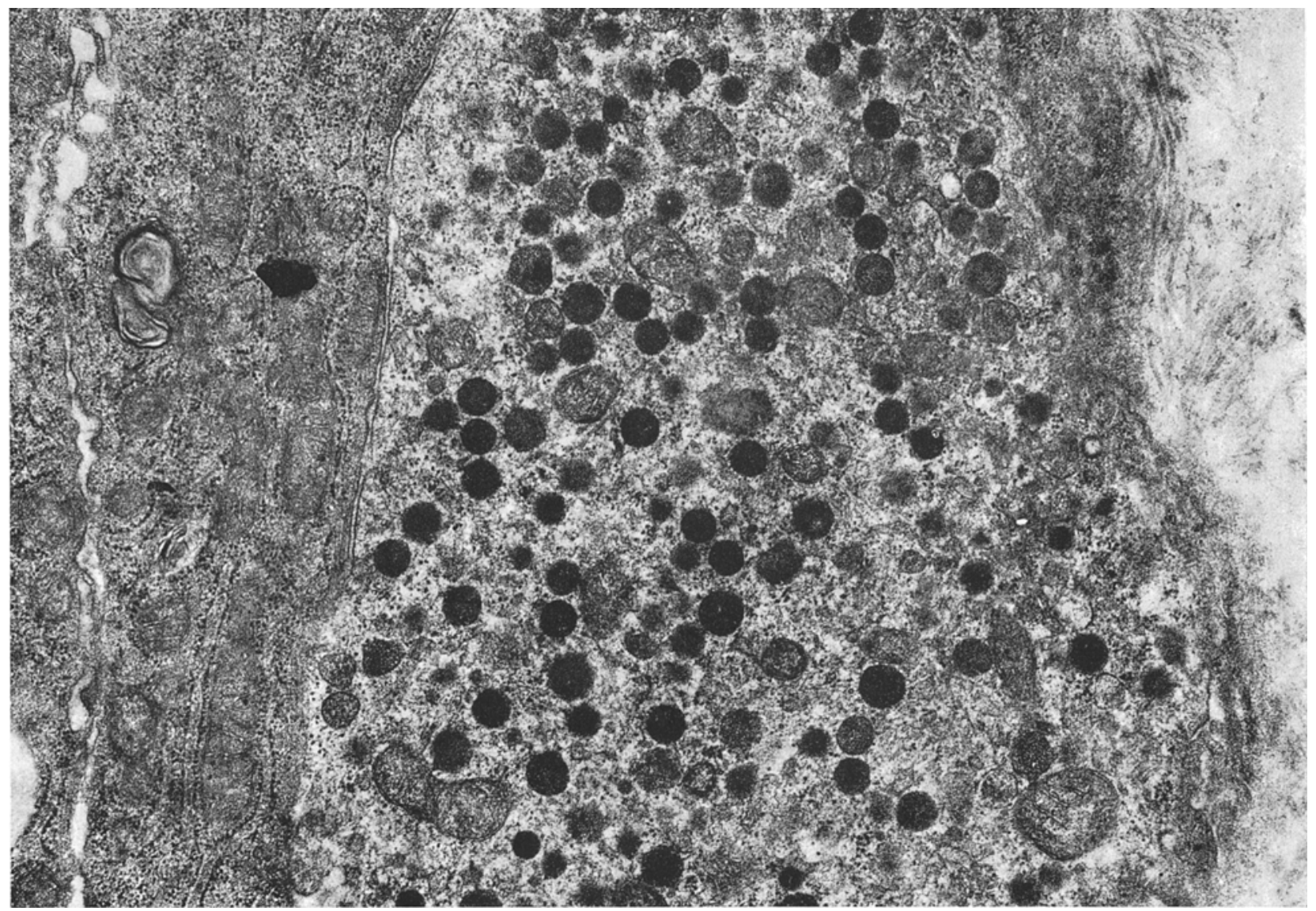

Fig. 13. A granular cell observed in the duodenal mucosa and exhibiting the same characteristics as an islet type IV cell. (Glutaraldehyde - Osmium $\times 21000$ )

bichromate reaction of Wood (1965) on pancreatic material.

Agranular cells. Such cells have been described, as a separate type by (Björkman et al. (1966), Bencosme et al. (1963), and Greider and Elliott (1964). We have not been able to identify them in our material. After primary osmic acid fixation we have observed apparently agranular cells, but, at close inspection, ghosts of membranous sacs were regularly seen. Therefore we suspect that the agranular cells of early authors are related to unsatisfactory fixation. Lacy (1961), Lazarus and Volk (1962), and Herman et al. (1964) suggested that in the course of the secretory cycle a cytoplasmic pole or even the entire eytoplasm of endocrine cells might become degranulated. We were unable to confirm in the printing of the photographs and to Mrs. M.L. Poeckens for expert preparation of the manuscript.

\section{References}

Anderson, P.J.: Purification and quantitation of glutaraldehyde and its effects on several enzyme activities in skeletal muscle. J. Histochem. Cytochem. 15, 652661 (1967)

Bencosme, S.A., Allen, R.A., Latta, H.L.: Electron microscopic study of functioning islet cell tumors. Anat. Rec. 136, 163 abstract (1960)

- - - Functioning pancreatic islet cell tumors studied electronmicroscopically. Amer. J. Path. 42, 1-22 (1963).

Bensley, R.R.: Studies of the pancreas of the guinea pig. Amer. J. Anat. 12, 297-388 (1911). 
Björkman, N., Hellerström, C., Hellman, B.: The ultrastructure of the islets of Langerhans in normal and obese-hyperglycemic mice. Z. Zellforsch. 58, 803-819 (1963).

- - - Petersson, B.: The cell types in the endocrine pancreas of the human fetus. Z. Zellforsch. 72, 425445 (1966). in the Zollinger-Ellison and Verner-Morrison syndrome. In: "The structure and metabolism of the pancreatic islets" ${ }^{\text {" }} 16$, p. 53-63. Eds. Falkmer, S., Hellman, B. and Täljedal, I. B. Oxford: Pergamon Press 1969.

- Theodossiou, A.: Die Relation der A- und B-Zellen in den Pankreasinseln bei Nichtdiabetikern und Diabetikern. Beiträge pathol. Anat. 117, S. 235-252 (1957).

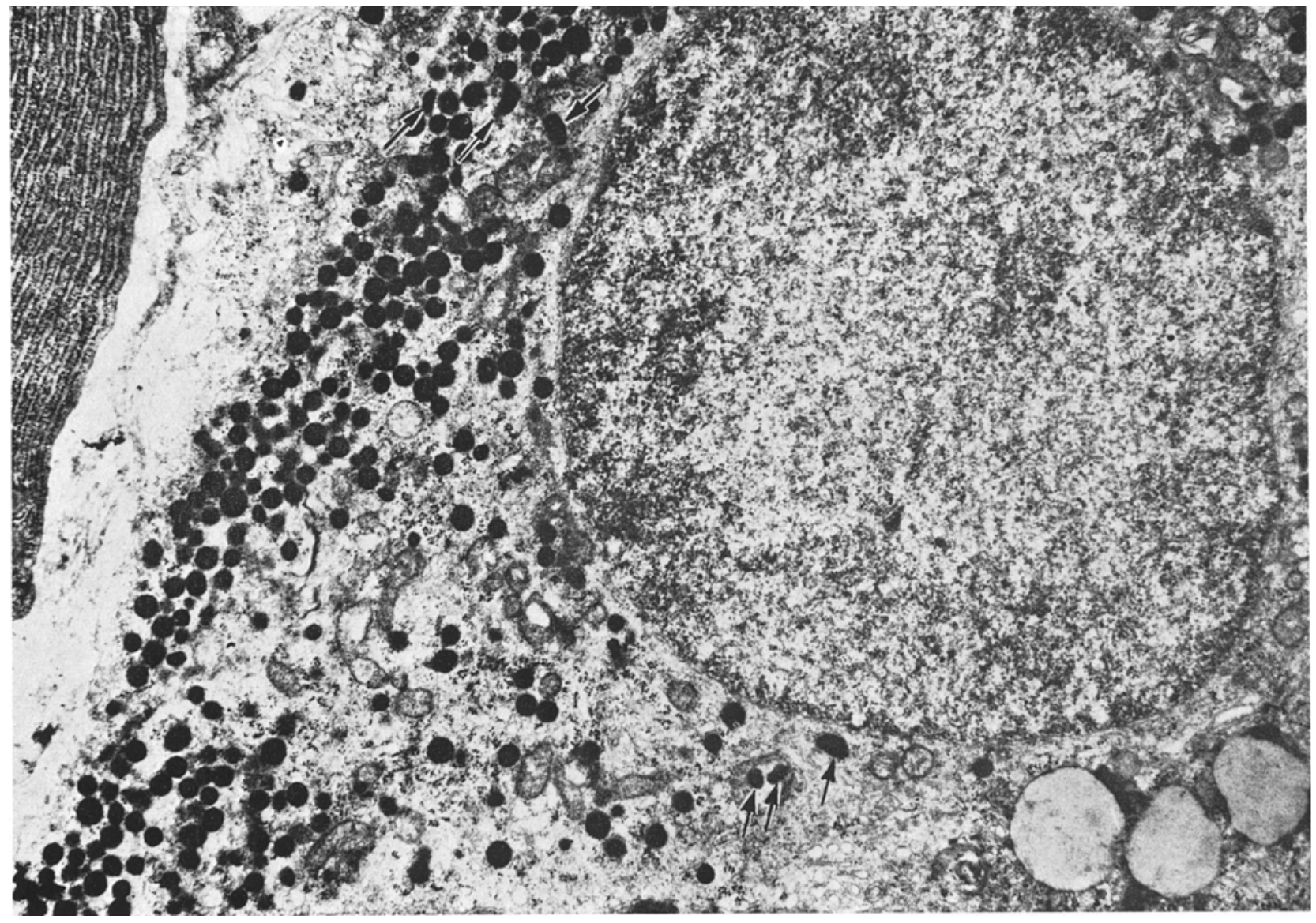

Fig. 14. A type $V$ cell in the pancreas showing typical, small, electron-dense and generally rounded granules, some of them, however, are elongated $(\neg)$ (Glutaraldehyde - Osmium $\times 16500)$

Björkman, N., Hellman, B.: Ultrastructure of the islets of Langerhans in the duck. Acta anat. 56, 348-367 (1964).

Bloom, W.: New type of granular cell in islet of Langerhans of man. Anat. Rec. 49, 363-371 (1931).

Boquist, L.: Intranuclear rods in pancreatic B cells. J. Cell. Biol. 43, $377-381$ (1969).

Cavallero, C., Solcia, E.: Cytological and eytochemical studies on the pancreatic islets. In: "The structure and metabolism of the pancreatic islets", p. 83-97. Ed. Brolin, S.E., Hellman, B. and Knutson, H. Oxford: Pergamon Press 1964.

Creutzfeldt, W., Creutzfeld, C., Perings, E.: Light and electron microscopic findings in three clinical cases of the Zollinger-Ellison syndrome. In: "Modern Aspects on Zollinger-Ellisonsyndrome and Gastrin, p. 85-100. Stuttgart: Georg Thieme 1969.

- Perings, E., Classen, M., Creutzfeldt, C.: Observations on the type and origin of the hormone-producing cells
Epple, A.: Weitere Untersuchungen über ein drittes Pankreashormon. Verh. Deut. Zool. Ges. 1965. Ergänz. z. Zool. Anz. 29, 459-470 (1966).

Forssman, W.G., Orci, L., Pictet, R., Renold, A.E., Rouiller, C.: The endocrine cells in the epithelium of the gastrointestinal mucosa of the rat. An electron microscope study. J. Cell. Biol. 40, 692-715 (1969).

Fujita, T.: The identification of the argyrophil cells of pancreatic islets with D cells. Arch. histol. jap. 25, 189197 (1964).

- D Zellen der Pankreasinseln beim Diabetes mellitus mit besonderer Berücksichtigung ihrer Argyrophilie. Z . Zellforsch. 69, 363-370 (1966).

- D Zellen, the third endocrine element of the pancreatic islet. Arch. histol. jap. 29, 1-40 (1968).

Gepts, W.: Contribution à l'étude morphologique des îlots de Langerhans au cours du diabète. Bruxelles: Les éditions "Acta Medica Belgica" 1957.

Gomori, G.: Observations with differential stains on hu- 
man islets of Langerhans. Amer. J. Path. 17, 395-406 (1941).

Greider, M.M., Bencosme, S.A., Lechago, J.: The human pancreatic islet cells and their tumors. I. The normal pancreatic islets. Lab. Invest. 22, 344-354 (1970).

Greider, M.H., Elliott, D.W.: Electron microscopy of human pancreatic tumors of islet cell origin. Amer. J. Path. 44, 664-678 (1964).

- Zollinger, R.: An electron microscopic study of islet cell adenomas. J. Amer, med. Ass. 186, 566-569 (1963).
Honjin, R., Takahaski, A., Maruyama, H., Murono, S., Hanyu, T. : Electron microscopy of a case of insulinoma. J. Electron. Microse. 14, 183-188 (1965).

Karnowsky, M.J. : A simple method for staining with lead at high $\mathrm{pH}$ in electron microscopy. J. biophys. biochem. Cytol. 11, 729- 732 (1961).

Kawanishi, H., Akazawa, Y., Machii, B. : Islets of Langerhans in normal and diabetic humans. Ultrastructure and histochemistry, with special reference to hyalinosis. Acta path. Jap. 16, 177-197 (1966).

Lacy, P.E.: Electron microscopy of the normal islets of

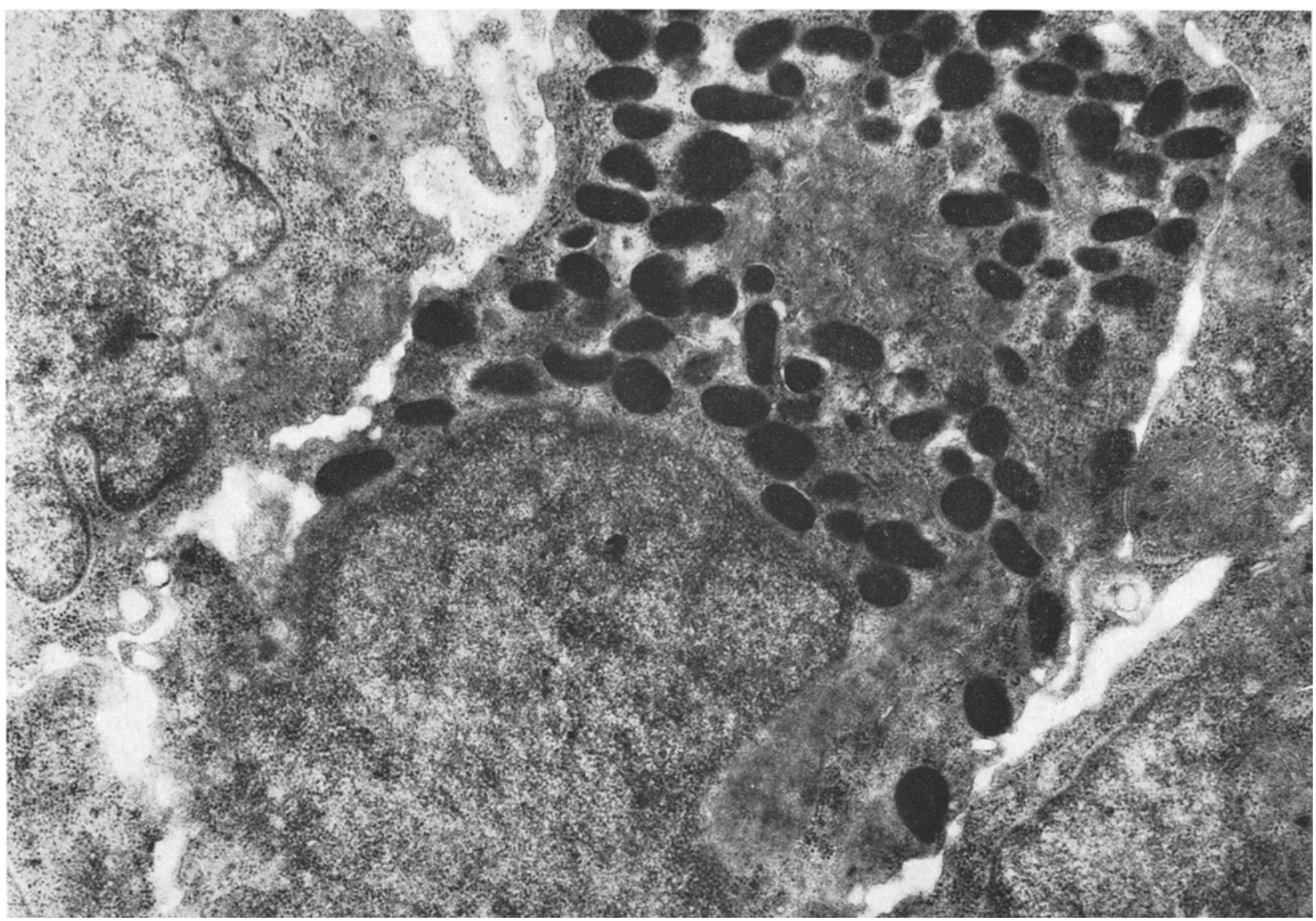

Fig. 15. A granular cell observed in the duodenal mucosa and to be compared with the islet type $V$ cell; the general characteristics are similar, but the granules are distinctly larger in the intestinal cell. (Glutaraldehyde - Osmium $\times 21000)$

- Me Guigan.: Immunofluorescence localisation of gastrin in islet cells of human pancreas. Amer. J. Path. (in press).

Hellman, B., Hellerström, C.: The specificity of the argyrophil reaction in the islets of Langerhans in man. Acta endocr. (Kbh.) 36, 22-30 (1961).

- Lernmark, A.: A possible role of the $\alpha 1$ and $\alpha 2$ cells as local regulators of insulin secretion. In: "The structure and metabolism of the pancreatic islets", 16, p. 453-462. Eds. Falkmer, S., Hellman, B. and Täljedal, I.B.Oxford: Pergamon Press 1969.

Herman, L., Sato, T., Fitzgerald, P.J.: Electron microscopic anatomy, p. 59-95. Ed. by Kurtz, S.M. New York: Academic Press 1964.
Langerhans. Studies in the dog, rabbit, guinea pig and rat. Diabetes 6, $418-507$ (1957).

- Electron microscopy of the beta cell of the pancreas. Amer. J. Med. 31, $851-859$ (1961).

Lacy, P.E.: Pancreatic beta cell. In: "Aetiology of diabetes mellitus and its complications" Ed. by Cameron, M.P. and O'Connor, M. Ciba Foundation Colloquia on Endocrinology. London: J. and A. Churchill, Ltd.

Lane, M.A.: The cytological characteristics of the areas of Langerhans. Amer. J. Anat. 7, 409-422 (1907).

Lazarus, S.S., Volk, B.W.: The pancreas in human and experimental diabetes. New York-London: Grune \& Stratton 1962

Lechago, J., Bencosme, S.A.: Endocrine-like cells of the 
dog gastric fundus, pylorus and duodenum. Lab. Invest. 22, 504 (1970) abstract.

- Greider, M.H, Bencosme, S. A.: Human pancreatic islet cells. Ultrastructural characteristics of their secretion granules. J. Cell. Biol. 39, 78 (1968) abstract.

Legg, P.G.: The fine structure and innervation of the beta and delta cells in the islet of Langerhans of the cat. Z. Zellforsch. 80, 307-321 (1967).

Lever, J.D., Findley, J.A.: Similar structural bases for the storage and release of secretory material in adrenomedullary and B pancreatic cells. Z. Zellforsch. 74, $317-324$ (1966).

Like, A.A.: The ultrastructure of the secretory cells of the islets of Langerhans in man. Lab. Invest. 16, 937951 (1967).

Lomský, R., Langr, F., Vortel, V.: Immunohistochemical demonstration of gastrin in mammalian islets of Langerhans. Nature 223, 618-619 (1969).

Munger, B.L.: The secretory cycle of the pancreatic islet alpha cell. Lab. Invest. 11, 885-901(1962).

- Caramia, F., Lacy, P.E.: The ultrastructural basis for the identification of cell types in the pancreatic islets. II. Rabbit, dog and opossum. Z. Zellforsch. 67, 776798 (1965).

Orci, L., Pictet, R., Forsmann, W.G., Renold, A.E., Rouiller, C.: Structural evidence for glucagon producing cells in the intestinal mucosa of the rat. Diabetologia 4, 56-67 (1968).

Paget, G.E.: Aldehyde-Thionin: A stain having similar properties to aldehyde-fuchsin. Stain Technol. 34, $223-226(1959)$.

Pearse, A.G.E., Coulling, I., Weavers, B., Friesen, S.: The endocrine polypeptide cells of the human stomach, duodenum and jejunum. Gut. 11, 649-658 (1970).

Porta, E.A., Roger, Y., Scott, R.F.: Amyloidosis of functioning islet cell adenomas of the pancreas. Amer. J. Path. 41, 623-627 (1962).

Potet, F., Martin, E., Thiery, J.P., Bader, J.P., Bonfils, S., Lambling, A.: Etude histologique et cytologique du pancréas endocrine tumoral et non tumoral dans le syndrome de Zollinger-Ellison. Rev. int. Hépat. 16, $737-761$ (1966).
Reedy, M.K.: Section staining for electron microscopy. Incompatibility of Methyl Nadic Anhydride with permanganates. J. Cell. Biol, 26, 309-311 (1965).

Reynolds, E.S.: The use of lead citrate a high pH as an electron opaque stain in electron microscopy. J. Cell. Biol. 17, 208-212 (1963).

Schultrich, S.: Elektronenmikroskopische Beiträge zum Bau des menschlichen Inselapparates. Endokrinologie 49, $105-125$ (1966).

Shibasaki, S., Ito, T.: Electron microscopic study on the human pancreatic islets. Arch. histol. jap. 31, 119-154 (1969).

Thiery, J.P., Bader, J.P.: Ultrastructure des îlots de Langerhans du pancréas humain normal et pathologique. An. Endocr. 27, 625 - 647 (1966).

Thomas, T.B.: Cellular components of the mammalian islets of Langerhans. Amer. J. Anat. 62, 31-58 (1937).

Van Assche, F.A.: The fetal endocrine pancreas. A quantitative morphological approach. Ortho Pharmaceutica - Thesis - Katholieke Universiteit Leuven, Belgium, 1970.

Volk, B.W., Goldner, M.G., Crowley, H.F.: The effect of prolonged growth hormone administration on the pancreatic alpha cells in normal and hypophysectonized rats. Metabolism 4, 491-502 (1955).

- Lazarus, S.S.: Ultrastructure of pancreatic B cells in severely diabetic dogs. Diabetes 13, 60-68 (1964).

Wood, J.G.: Electron microscopic localization of 5-hydroxytryptamine. Texas Rep. Biol. Med. 23, 828837 (1965).

Zagury, D.: Etude des cellules sécrétoires du pancréas chez le rat et l'homme. Bull. Ass. Anat. 114, 857-862 (1962).

- Brux, J., Ancla, M., Leger, L.: Etude des îlots de Langerhans du pancréas humain au microscope électronique. Presse médicale 69, 887-890 (1961).

Prof. Dr. W. Gepts

Faculteit Geneeskunde en Farmacie

Universitajr Ziekenhuis Brugmann

B-1020 Brussels

Vam Gehuchtenplein 4 